\title{
Water quality in four reservoirs of the metropolitan region of São Paulo, Brazil
}

\author{
Qualidade das águas de quatro reservatórios da Região Metropolitana de São Paulo, Brazil
}

Denise Amazonas Pires ${ }^{1,2}$, Andrea Tucci ${ }^{3}$, Maria do Carmo Carvalho ${ }^{2}$ and

Marta Condé Lamparelli ${ }^{2}$

${ }^{1}$ Programa de Pós-graduação em Biodiversidade Vegetal e Meio Ambiente, Instituto de Botânica de São Paulo, Av. Miguel Stéfano, 3687, Água Funda, CEP 04301-012, São Paulo, SP, Brazil e-mail: de.amazonas@gmail.com

${ }^{2}$ Companhia Ambiental do Estado de São Paulo - CETESB, Av. Prof. Frederico Hermann Junior, 345, Alto de Pinheiros, CEP 05459-900, São Paulo, SP, Brazil

e-mail: marcarvalho@sp.gov.br; mlamparelli@sp.gov.br

${ }^{3}$ Núcleo de Pesquisa em Ficologia, Instituto de Botânica, Av. Miguel Stéfano, 3687, Água Funda,

CEP 04301-012, São Paulo, SP, Brazil

e-mail: atuccic@ig.com.br

\begin{abstract}
Aim: This paper describes some limnological variables of four reservoirs with different trophic status (Billings, Guarapiranga, Jundiaí and Paiva Castro) of the Metropolitan Region of São Paulo, Brazil, aiming to characterize the water quality in these reservoirs. Methods: Water sampling occurred between October 2011 and September 2012, on subsurface, at the pelagic compartment. Physical and chemical characteristics of water were evaluated, and the Trophic State Index (TSI) was calculated. Multivariate Principal Components Analysis (PCA) was used to ordinate sampling sites and periods in relation to environmental data. Results: Two reservoirs were classified as eutrophic (Billings and Guarapiranga), one as mesotrophic (Jundiaí) and one as oligotrophic (Paiva Castro). The highest concentrations of total phosphorus, nitrogen and chlorophyll $a$ were recorded in the eutrophic reservoirs. The lowest values of dissolved oxygen concentration were registered at Guarapiranga reservoir. Residence time in Paiva Castro reservoir was very low (one day); on the other hand, the highest value was recorded in Billings reservoir: 428 days.
\end{abstract}

Keywords: eutrophication; limnology; nitrogen; phosphorus; reservoir.

Resumo: Objetivo: $\mathrm{O}$ trabalho descreve alguns parâmetros limnológicos de quatro reservatórios com estados tróficos diferentes (Billings, Guarapiranga, Jundiaí e Paiva Castro) da Regiáo Metropolitana de Sáo Paulo, Brasil, com o objetivo de caracterizar a qualidade da água nesses ambientes. Métodos: As amostragens foram realizadas entre outubro de 2011 e setembro de 2012, na subsuperfície, no compartimento pelágico. Foram avaliadas características físicas e químicas da água e calculado o Índice de Estado Trófico (IET). Análise multivariada de Componentes Principais (ACP) foi utilizada ordenando os pontos e períodos de coleta em relação aos dados ambientais. Resultados: Dois reservatórios foram classificados como eutróficos (Billings e Guarapiranga), um como mesotrófico (Jundiaí) e um como oligotrófico (Paiva Castro). As maiores concentraçóes de fósforo total, nitrogênio e clorofila-a foram registradas nos reservatórios eutróficos. Os menores valores de oxigênio dissolvido foram registrados no Guarapiranga. O tempo de residência no reservatório Paiva Castro foi muito baixo (um dia), enquanto que o maior valor foi registrado no reservatório Billings: 428 dias.

Palavras-chave: eutrofização; limnologia; nitrogênio; fósforo; reservatório. 


\section{Introduction}

Water quality has been the subject of recent studies in Brazil (Buzelli \& Cunha-Santino, 2013; Cardoso-Silva et al., 2014; Oliveira et al., 2014) and abroad (Akoto \& Abankwa, 2014; Dawson et al., 2015), specially because of pressure on hydric resources, due to increase in population density and the discharge of domestic and industrial effluents in water bodies, resulting in artificial eutrophication.

The Metropolitan Region of Sáo Paulo (MRSP) has eight water supply systems, composed of reservoirs and rivers, which provide 74.2 thousand $\mathrm{m}^{3}$ for a growing population (SABESP, 2015a). The largest system is Cantareira, followed by Guarapiranga and Alto Tietê, in which the reservoirs studied here are included. Unfortunatelly, most reservoirs suffer because of unplanned urban occupation, which implicates in further impacts in water quality (Tundisi, 2005), and therefore this region is considered the second worldwide in terms of precarious water resources, partly due to the intense anthropogenic impact that it receives (Whately \& Diniz, 2009). Among the existing impacts, the contribution of wastewater should be particularly stressed, resulting in accelerated eutrophication and frequent blooms of algae and cyanobacteria (Sant'Anna et al., 2008). In 1992, Tundisi \& Tundisi (1992) mentioned that between $30-50 \%$ of aquatic environments around the world were eutrophic, with highest trophic status in those located near urban centers and agricultural areas, where discharges of nitrogen and phosphorus are more intense. According to Di Bernardo et al. (2010), reversing the process of artificial eutrophication in aquatic environments is extremely difficult and costly.

In the last years (2013 to 2015), an exceptional drought has affected most of eastern Brazil, with a prolonged period of above average temperatures coupled with low precipitation rates (Getirana, 2015). This drought affected all drinking water supply systems of MRSP, but specially Cantareira System, which used to provide $33 \mathrm{~m}^{3} \cdot \mathrm{s}^{-1}$ of water for 8.8 million people, reduced to $14 \mathrm{~m}^{3} \cdot \mathrm{s}^{-1}$ in March 2015, and Alto Tietê water system, supplying in the same period $12 \mathrm{~m}^{3} \cdot \mathrm{s}^{-1}$ of water for approximately 3.5 million people, instead of its full capacity of $15 \mathrm{~m}^{3} \cdot \mathrm{s}^{-1}$ (SABESP, 2015a; SABESP, 2015b; ANA, 2015; Escobar, 2015).

Although also affected by the climatic conditions, other reservoirs such as Billings are increasing its contribution, in order to avoid water supply shortage, despite its poor water quality.
Extreme hydrological events such as droughts have a profound impact on society and affect water supply, food production and energy generation (Getirana, 2015). Intense fluctuations in the volume of water stored in reservoirs can affect water quality, not only because of alterations in residence time, but also because it can increase bank erosions, resulting in higher turbidity and other negatives impacts (Straškraba \& Tundisi, 2013).

Considering the economic and ecological importance of these reservoirs, this study aims to characterize de water quality in four reservoir of the MRSP, of three different Water Supply Systems (Alto Tietê, Cantareira and Guarapiranga), with different trophic state, in order to provide information for its management and monitoring. These data are important for further studies aiming to compare water quality before and after this exceptional drought.

\section{Material and Methods}

\subsection{Study area}

Four reservoirs of the MRSP were selected, considering historical data of their trophic state (Figure 1). Table 1 contains some important features of each reservoir. These reservoirs are located near highly populated urban areas and suffer with population growth and lack of basic sanitation, receiving pollutant loads, mainly of domestic origin. Their uses includes recreation, fishing, domestic and industrial effluents dilution.

Billings reservoir is located on the southeast region of Sáo Paulo and is one of the most important reservoirs of MRSP (Table 1). Among the uses listed above, it includes public supply (through Taquecetuba arm) and sometimes electricity generation at Henry Borden power plant (Carvalho et al., 1997). Due to its configuration, the principal water flow passes mainly through the longest central axis of the reservoir, which measures more than $20 \mathrm{~km}$, exiting at the Summit Control, where the sampling site is located (CETESB, 2003).

Guarapiranga reservoir is located on the southwest region of São Paulo and is the second largest source of water supply of MRSP (Table 1). This reservoir receives water transposed from two other watersheds: from the Capivari river to the Embu-Guaçu river and the reversal of water from Billings reservoir through the Taquacetuba arm, operating since 2000 (Whately \& Cunha, 2006). Among other uses cited above, the reservoir is used for public water supply. The sampling site is located 


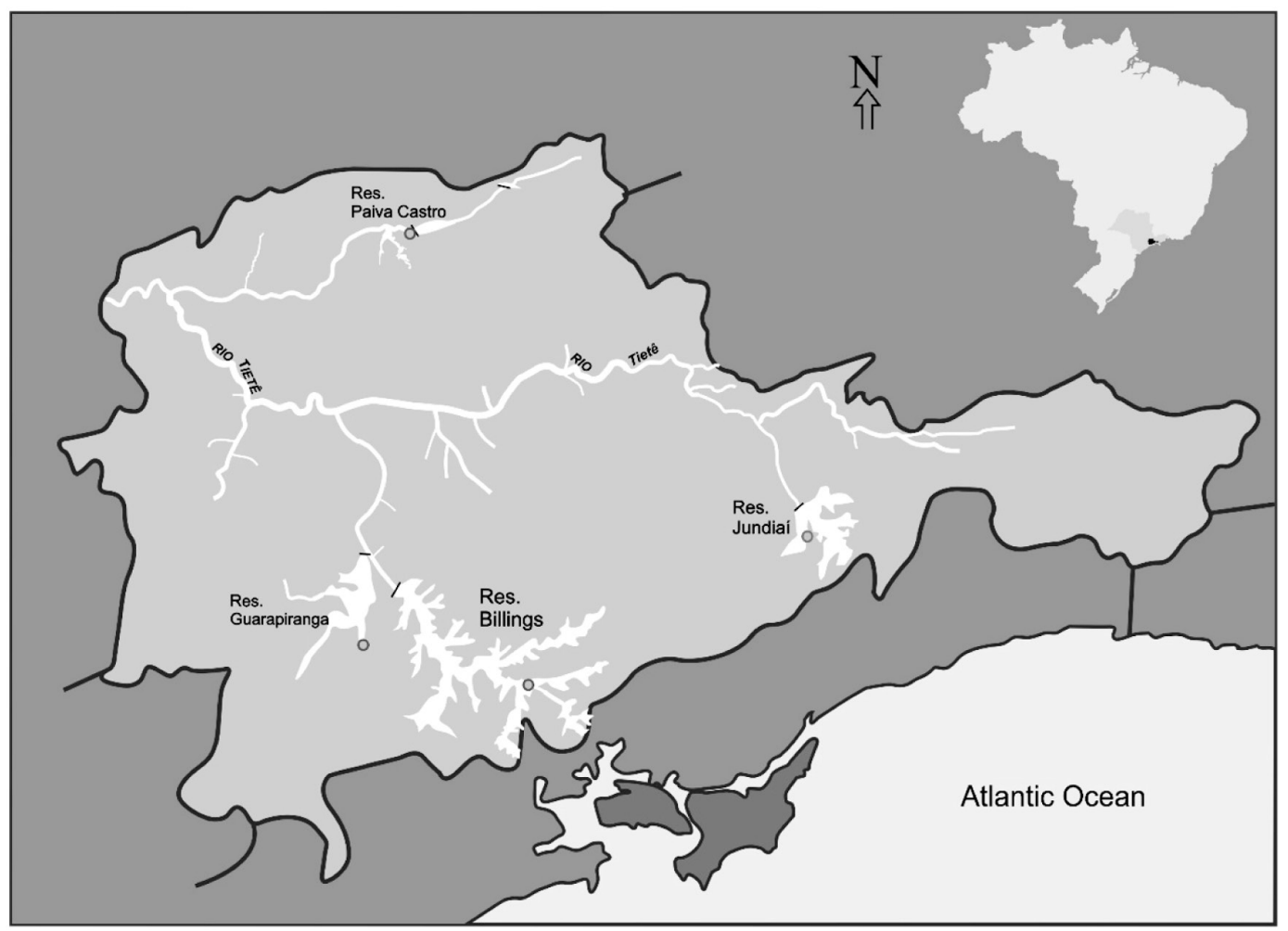

Figure 1. Metropolitan region of São Paulo state, highlighting the four reservoirs included in the study: Billings, Guarapiranga, Jundiaí and Paiva Castro. Sampling sites are marked with a dot in each reservoir.

Table 1. Characterization of the studied reservoirs: Billings, Guarapiranga, Jundiaí and Paiva Castro.

\begin{tabular}{|c|c|c|c|c|}
\hline & Billings & Guarapiranga & Jundiaí & Paiva Castro \\
\hline Sampling site & Summit Control & $\begin{array}{l}\text { Parelheiros river } \\
\text { mouth }\end{array}$ & $\begin{array}{l}\text { Middle of the } \\
\text { reservoir }\end{array}$ & $\begin{array}{l}\text { Middle of the } \\
\text { reservoir }\end{array}$ \\
\hline $\begin{array}{l}\text { Sampling site } \\
\text { coordinates }\end{array}$ & $\begin{array}{l}23^{\circ} 49^{\prime} \mathrm{S} \\
46^{\circ} 31^{\prime} \mathrm{W}\end{array}$ & $\begin{array}{l}23^{\circ} 45^{\prime} \mathrm{S} \\
46^{\circ} 43^{\prime} \mathrm{W}\end{array}$ & $\begin{array}{l}23^{\circ} 38^{\prime} \mathrm{S} \\
46^{\circ} 11^{\prime} \mathrm{W}\end{array}$ & $\begin{array}{l}23^{\circ} 20^{\prime} \mathrm{S} \\
46^{\circ} 39^{\prime} \mathrm{W}\end{array}$ \\
\hline Construction year & 1927 & 1909 & 1992 & 1973 \\
\hline Medium depth (m) & 15.0 & 3.5 & 6.0 & 13.0 \\
\hline Drainage area $\left(\mathrm{km}^{2}\right)$ & 560 & 640 & 111 & 314 \\
\hline Volume $\left(\mathrm{m}^{3}\right)$ & $1.2 \times 10^{9}$ & $1.94 \times 10^{8}$ & $6.0 \times 10^{7}$ & $7.0 \times 10^{6}$ \\
\hline Surface area $\left(\mathbf{k m}^{2}\right)$ & 127 & 33 & 17.5 & 5.1 \\
\hline $\begin{array}{l}\text { Residence Time } \\
\text { during studied period } \\
\text { (days) }\end{array}$ & 428 & 105 & 63 & 1 \\
\hline $\begin{array}{l}\text { Mean volume during } \\
\text { studied period (\%) }\end{array}$ & 64.88 & 68.65 & 60.48 & 47.55 \\
\hline $\begin{array}{l}\text { Mean water supply } \\
\text { intake }\left(\mathrm{m}^{3} / \mathrm{s}\right)\end{array}$ & 2 & 14 & 15 & 32 \\
\hline Water Supply System & Guarapiranga & Guarapiranga & Alto Tietê & Cantareira \\
\hline
\end{tabular}

near the mouth of the Parelheiros river, which receives $2.0 \mathrm{~m}^{3} / \mathrm{s}$ pumped from Billings reservoir.

Jundiaí reservoir is located on the southeast region of São Paulo state (Table 1) and is part of the Alto Tietê system. Its uses include public water supply (through its connection with Taiaçupeba reservoir). The sampling site is located in the middle of the reservoir, in front of an arm where water is transposed to Taiaçupeba reservoir.
Paiva Castro reservoir is located on the northwest region of Sáo Paulo and is part of the Cantareira system (Table 1). This system has five reservoirs connected through channels and tunnels, and Paiva Castro is the penultimate of them. Formed by the damming of the Juqueri river, the reservoir is located mainly in Mairiporã municipality. The sampling site is located in the middle of the reservoir. 


\subsection{Hidrological variables}

Pluviometric precipitation data was obtained from CETESB (2012, 2013; Figure 2). The residence time of each reservoir was calculated for the period of study as recommended by Nogueira et al. (1999). Data were obtained from SABESP (Basic Sanitation Company of São Paulo State), EMAE (Metropolitan
Enterprise of Water and Energy SA) and CETESB (Personal Communication, April 2013; Table 1).

Sampling was carried out between October 2011 and September 2012, bimonthly. Water samples were collected subsuperficially using a van Dorn sampler (Brandão, 2011), and the water variables listed in Table 2 were measured.

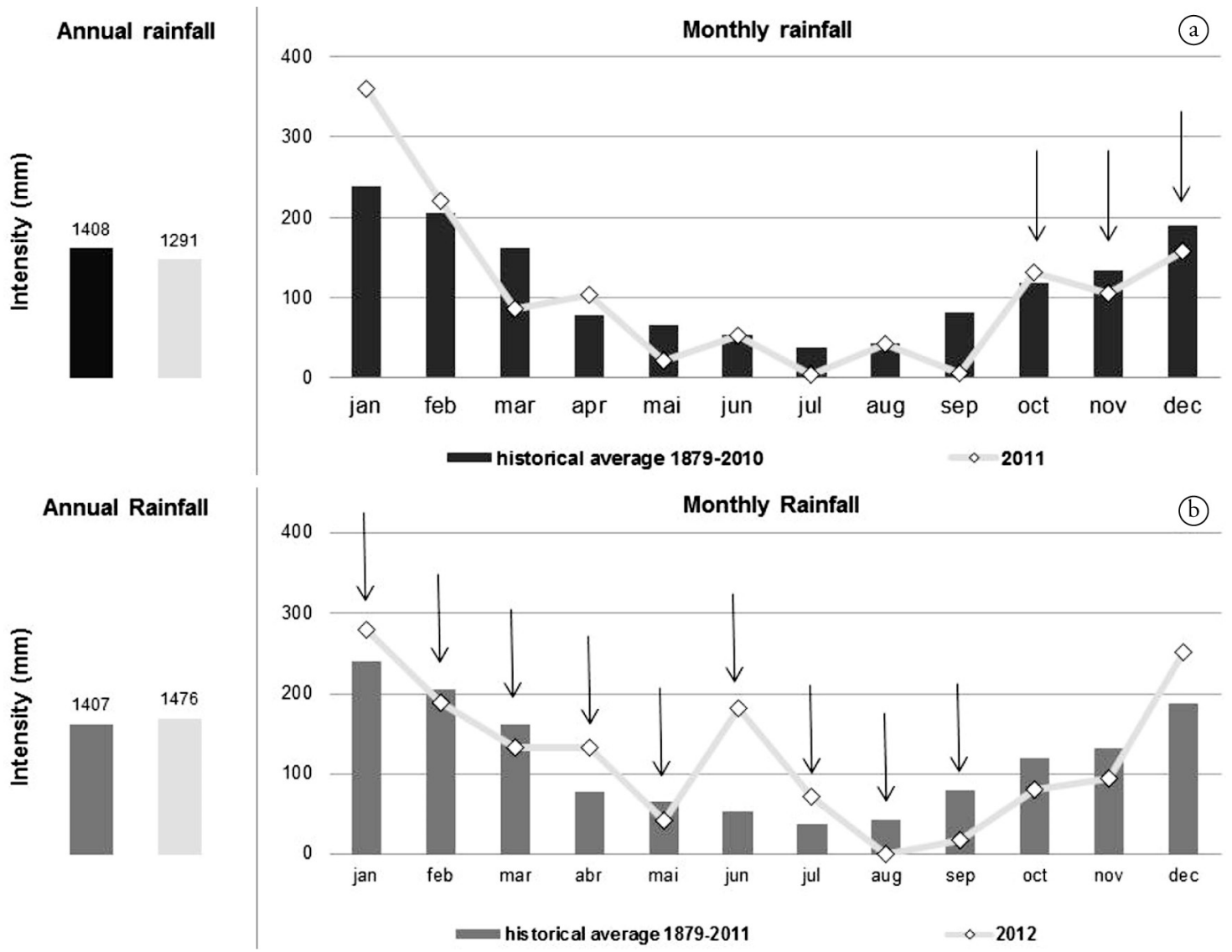

Figure 2. Average monthly precipitation regime (in mm) at Alto Tietê basin in 2011 (a) and 2012 (b). The dark bar corresponds to the historical average and the line represents the monthly average between January - December of each year. The arrows represent the sampling periods of this study (CETESB, 2012, 2013).

Table 2. Water variables and their respective methods (CETESB, 2013).

\begin{tabular}{|c|c|}
\hline Variables & Methods \\
\hline Water Temperature & Multiparameter sonde YSI 6600 V2 \\
\hline \multicolumn{2}{|l|}{ Electrical Conductivity } \\
\hline \multicolumn{2}{|l|}{$\mathrm{pH}$} \\
\hline \multicolumn{2}{|l|}{ Dissolved Oxigen } \\
\hline Water Transparency & Secchi Disk \\
\hline Nitrate $\left(\mathrm{mg} \mathrm{NO}^{3}-\mathrm{N} . \mathrm{L}^{-1}\right)$ & Ionic Chromatography (APHA, 2005) \\
\hline Ammoniacal Nitrogen $\left(\mathrm{mg} \mathrm{NH}_{3}-\mathrm{N} \cdot \mathrm{L}^{-1}\right)$ & Automatic Spectrophotometry with isocyanuric acid (APHA, 2005) \\
\hline Total Kjeldahl nitrogen (mg N.L-1) & Automatic Spectrophotometry with isocyanuric acid (APHA, 2005) \\
\hline Total Phosphorus (mg P.L-1) & $\begin{array}{l}\text { Automatic Spectrophotometry with ammonium molybdate and ascorbic acid } \\
\text { (APHA, 2005) }\end{array}$ \\
\hline Chlorophyll a (mg. $\left.\mathrm{L}^{-1}\right)$ & Spectrophotometry with acetone extraction (APHA, 2005) \\
\hline Alcalinity (mg CaCO $\left.{ }^{3} \cdot \mathrm{L}^{-1}\right)$ & Potenciometry with combined eletrodus (APHA, 2005) \\
\hline Turbidity (UNT) & Turbidimetry (APHA, 2005) \\
\hline
\end{tabular}


Multivariate Principal Components Analysis (PCA; Goodall 1954 apud Valentin 2000) was used to ordinate sampling sites and periods in relation to environmental data (Figure 3). PCA was carried out using PC-ORD, version 6.0 for Windows (McCune \& Mefford, 2011).

The Trophic State Index (TSI) was calculated according to CETESB (2013), without considering the Secchi Disk transparency, since this parameter can be affected by turbidity due to suspended material and not only by the density of planktonic organisms. Limits used are: ultra-oligotrophic (TSI $\leq 47)$, oligotrophic $(47<\mathrm{TSI} \leq 52)$, mesotrophic $(52<\mathrm{TSI} \leq 59)$, eutrophic $(59<\mathrm{TSI} \leq 63)$, supereutrophic $(63<\mathrm{TSI} \leq 67)$ and hypereutrophic (TSI > 67).

\section{Results}

In 2011, sampling periods were typical, considering the precipitation regime, with increased precipitation in early spring, and values close to the historical average (Figure 2a). In 2012, precipitation in the months of January, April, June and July were higher than the historical average, especially in June, and in the months of August and September were lower than the historical average (Figure 2b).

Residence time for each reservoir was calculated, with the highest value recorded in Billings reservoir (428 days) and the lowest in Paiva Castro reservoir (1 day; Table 1). TSI for the studied period was calculated for each sampling site in each reservoir, and they were classified as eutrophic (Billings and Guarapiranga), mesotrophic (Jundiaí) and oligotrophic (Paiva Castro; Table 3). Figure 3 shows that average chlorophyll $a$ has a great positive correlation with residence time for the studied period.

Water temperature, electrical conductivity, $\mathrm{pH}$, dissolved oxygen, water transparency, nitrate, ammoniacal nitrogen, total Kjeldahl nitrogen, total phosphorus, chlorophyll $a$, turbidity and alkalinity values are shown in Table 3.

PCA performed with the above limnological variables, including chlorophyll $a$, explained $69.86 \%$ of data variation on the first two axes (Figure 4). The samples from Billings and Guarapiranga reservoirs were clearly separated from the other two reservoirs, in the left side of axis 1, being positively correlated with higher values of nitrogen, total phosphorus, alkalinity and conductivity. On the other side of this axis, samplings from Jundiai and Paiva Castro reservoir were ordered, mainly associated with higher values of transparency and dissolved oxygen. The down side of axis 2 ordinated all Billings samples, positively correlated with higher values of $\mathrm{pH}$, water temperature and turbidity. Samples collected between October 2011 and April 2012 in Jundiaí and Paiva Castro reservoirs were also slightly influenced by these variables, compared with results from the same sites obtained during the dry season (June to September 2012).

\section{Chlorophyll a x Residence Time}

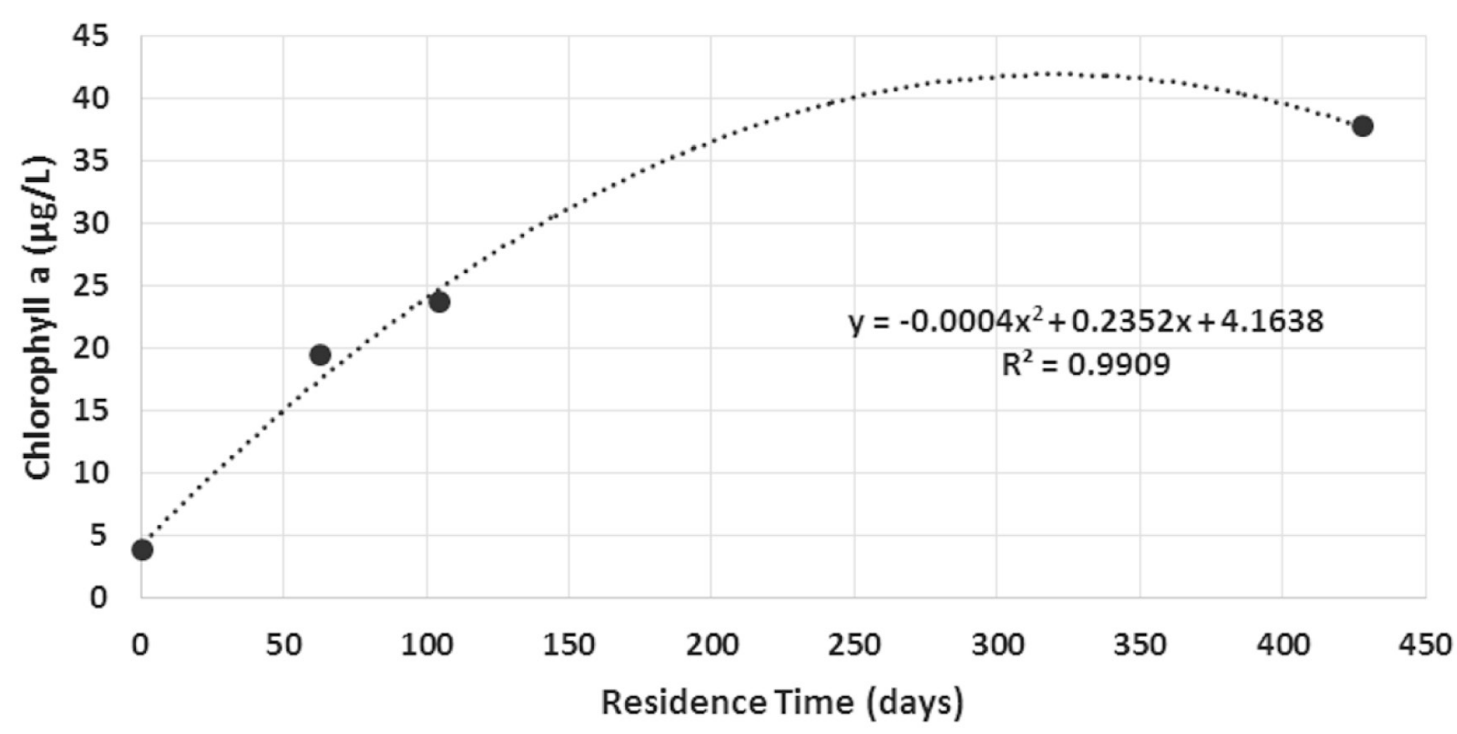

Figure 3. Average Chlorophyll $a\left(\mu \mathrm{g} . \mathrm{L}^{-1}\right)$ in relation to Residence time (days) during the study period. (PC) Paiva Castro reservoir; (JN) Judiaí reservoir; $(\mathrm{G})$ Guarapiranga reservoir; (BL) Billings reservoir. 
Table 3. Statistical summary of the limnological variables from the studied reservoirs. Number of samples analyzed for each variable in each reservoir was 6 .

\begin{tabular}{|c|c|c|c|c|c|c|c|c|}
\hline & \multicolumn{2}{|c|}{ Billings } & \multicolumn{2}{|c|}{ Guarapiranga } & \multicolumn{2}{|c|}{ Jundiaí } & \multicolumn{2}{|c|}{ Paiva Castro } \\
\hline & $\begin{array}{l}\text { Mean } \\
\text { Values }\end{array}$ & $\begin{array}{l}\text { Standard } \\
\text { Deviation }\end{array}$ & $\begin{array}{l}\text { Mean } \\
\text { Values }\end{array}$ & $\begin{array}{l}\text { Standard } \\
\text { Deviation }\end{array}$ & $\begin{array}{l}\text { Mean } \\
\text { Values }\end{array}$ & $\begin{array}{l}\text { Standard } \\
\text { Deviation }\end{array}$ & $\begin{array}{l}\text { Mean } \\
\text { Values }\end{array}$ & $\begin{array}{l}\text { Standard } \\
\text { Deviation }\end{array}$ \\
\hline Water Temperature & 22.23 & 2.79 & 21.94 & 3.08 & 22.56 & 3.00 & 23.25 & 2.91 \\
\hline $\begin{array}{l}\text { Electrical Conductivity } \\
\left(\mu \mathrm{S} . \mathrm{cm}^{-1}\right)\end{array}$ & 151.83 & 7.36 & 167.50 & 41.72 & 22.56 & 3.00 & 36.17 & 1.60 \\
\hline $\mathrm{pH}$ & 8.35 & 0.68 & 7.11 & 0.27 & 7.21 & 0.55 & 7.38 & 0.49 \\
\hline $\begin{array}{l}\text { Dissolved Oxygen } \\
\left(\mathrm{mg} \cdot \mathrm{L}^{-1}\right)\end{array}$ & 8.53 & 1.54 & 4.98 & 1.49 & 8.00 & 0.73 & 8.16 & 0.56 \\
\hline Transparency (m) & 0.92 & 0.33 & 0.85 & 0.21 & 1.19 & 0.36 & 1.43 & 0.16 \\
\hline Nitrate $\left(m g \cdot L^{-1}\right)$ & 0.23 & 0.05 & 0.42 & 0.16 & 0.15 & 0.05 & 0.17 & 0.05 \\
\hline $\begin{array}{l}\text { Ammoniacal N } \\
\left(\mathrm{mg}^{\left.-\mathrm{L}^{-1}\right)}\right.\end{array}$ & 0.19 & 0.10 & 1.10 & 0.83 & $<0.10$ & - & 0.12 & 0.04 \\
\hline $\begin{array}{l}\text { Total Kjeldahl N } \\
\left(\mathrm{mg}^{\left.-\mathrm{L}^{-1}\right)}\right.\end{array}$ & 1.05 & 0.31 & 1.99 & 1.11 & 0.60 & 0.12 & 0.62 & 0.15 \\
\hline Total P (mg. $\left.\mathrm{L}^{-1}\right)$ & 0.32 & 0.65 & 0.14 & 0.11 & 0.04 & 0.02 & $<0.007$ & - \\
\hline Chlorophyll a $\left(\mu \mathrm{g} \cdot \mathrm{L}^{-1}\right)$ & 40.48 & 15.88 & 29.31 & 21.10 & 20.25 & 6.18 & 4.15 & 1.64 \\
\hline Alcalinity $\left(\mathrm{mg} \cdot \mathrm{L}^{-1}\right)$ & 38.77 & 4.73 & 45.92 & 16.23 & 10.11 & 2.41 & 12.27 & 2.06 \\
\hline Turbidity (UNT) & 11.6 & 7.3 & 4.9 & 3.1 & 3.1 & 1.1 & 3.2 & 1.3 \\
\hline TSI (annual average) & 63.31 & & 61.87 & - & 58.48 & - & 50.7 & - \\
\hline
\end{tabular}

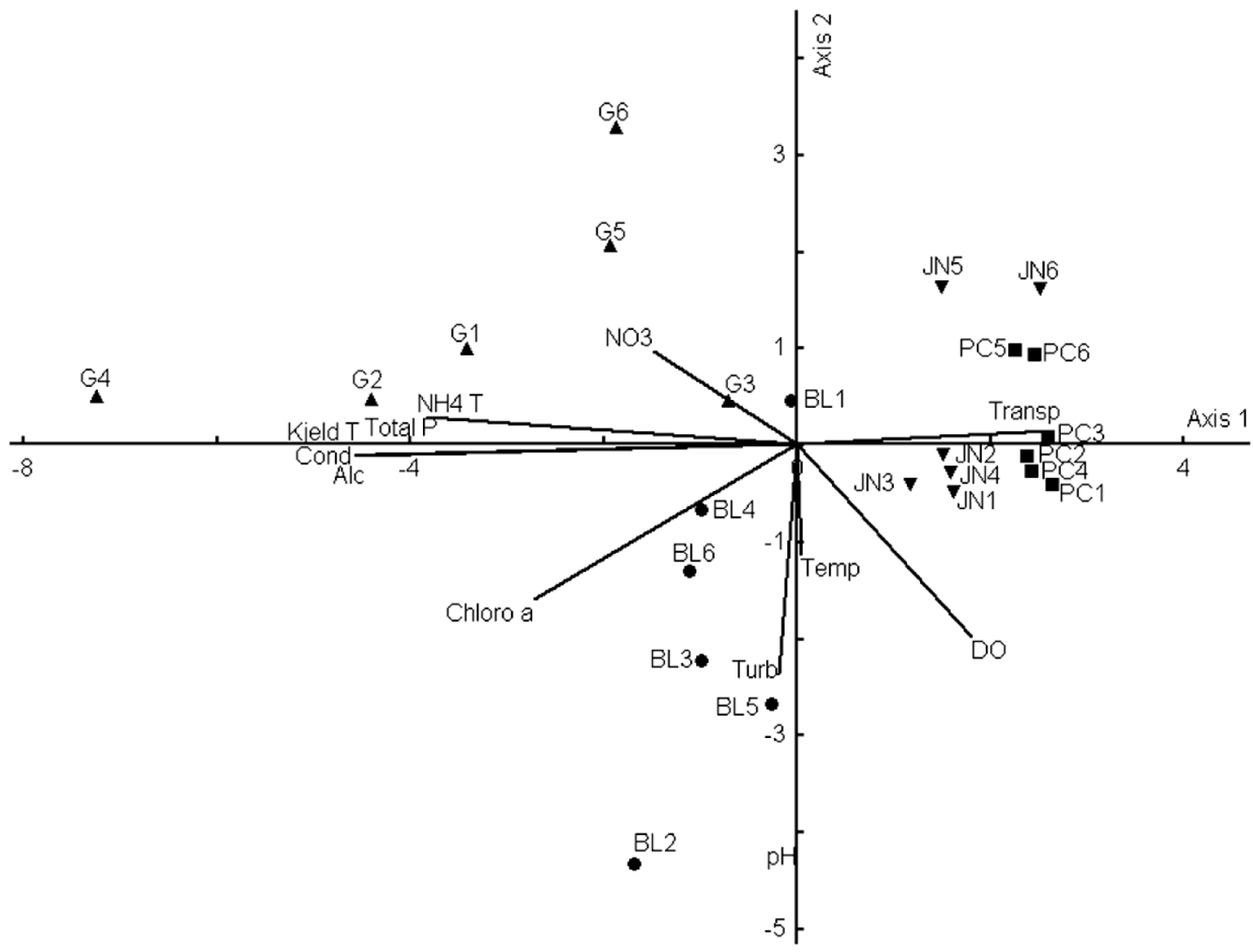

Figure 4. PCA of limnological variables and scores for the sampling sites during the studyied period. G: Guarapiranga reservoir; JN: Jundiaí reservoir; BL: Billings reservoir; PC: Paiva Castro reservoir; Transp: Transparency; OD: dissolved oxygen; Temp: water temperature; Turb: turbidity; Cond: conductivity; Alc: Alkalinity; $\mathrm{NO}_{3}$ : nitrate; $\mathrm{NH}_{4} \mathrm{~T}$ : ammoniacal nitrogen; KjeldT: Total kjeldahl nitrogen; Total P: Total Phosphorus; Chloro a: Chlorophyll $a$. For correlation of variables with principal components, see Table 4. 
Table 4. Loadings of limnological variables on the first two principal components (PC) and the proportion of variance explained by each component.

\begin{tabular}{lrr}
\hline \multirow{2}{*}{ Limnological Variable } & \multicolumn{2}{c}{ Principal Components } \\
\cline { 2 - 3 } & Axis 1 & Axis 2 \\
\hline Conductivity & -0.920 & -0.156 \\
pH & -0.042 & -0.894 \\
Total Phosphorus & -0.868 & 0.014 \\
Water Temperature & 0.103 & -0.473 \\
Transparency & 0.719 & 0.171 \\
Turbidity & -0.194 & -0.680 \\
Alcalinity & -0.943 & -0.162 \\
Dissolved Oxygen & 0.593 & -0.620 \\
Nitrate & -0.536 & 0.433 \\
Amoniacal Nitrogen & -0.862 & 0.238 \\
Total Kjeldahl Nitrogen & -0.912 & 0.036 \\
Chlorophyll a & -0.726 & -0.560 \\
Total & $\mathbf{5 0 . 4 9 \%}$ & $\mathbf{1 9 . 3 7 \%}$ \\
\hline
\end{tabular}

\section{Discussion}

Reservoirs located in densely populated regions receive discharges of nutrients, organic compounds and heavy metals that impair water quality and threaten aquatic biota and human health (Ishii $\&$ Sadowsky, 2008). That is the case of the four reservoirs of our study.

According to TSI, for the studied period, Billings and Guarapiranga reservoirs were characterized as eutrophic environments, Jundiaí reservoir as mesotrophic and Paiva Castro reservoir as oligotrophic. PCA performed with eleven abiotic variables and chlorophyll $a$ from the four reservoir corroborates TSI results, with the two eutrophic environments grouped in the left side of axis 1, related to higher concentrations of nutrients and chlorophyll $a$, and the other reservoirs grouped in the right side, with higher concentrations of dissolved oxygen and transparency. These results are in agreement with those presented by CETESB (2013) and other studies conducted in Billings (Cardoso-Silva et al., 2014; Wengrat \& Bicudo, 2011; Cunha et al., 2011; Moschini-Carlos et al., 2010) and Guarapiranga (Fontana et al., 2014) reservoirs in different sampling sites.

Residence time is associated with major differences in water quality between reservoirs (Straškraba \& Tundisi, 2013). According to Schindler (2006), the rate of water renewal is an important modifier of nutrients concentrations in aquatic ecosystems. Other authors also pointed that fluctuations in water level and residence time in reservoirs can strongly affect the phytoplankton community, acting directly upon the maintenance of these organisms in the water column (Reynolds, 2006; Bernhardt et al., 2008). Besides, short residence time causes biomass loss due to hydraulic washing and mechanical shock between phytoplankton cells (Kimmel et al., 1990; Straskraba et al., 1993). According to Henry et al. (1985), the development of phytoplankton requires a residence time of at least 2 or 3 weeks to allow significant growth of organisms. This minimum time was observed in Billings, Guarapiranga and Jundiaí reservoirs, but not in Paiva Castro reservoir, where rapid flow may have reduced nutrient availability and chlorophyll $a$ concentrations. We found positive correlation between residence time and chlorophyll $a$, an indicator of algal biomass as well as eutrophication. Therefore, residence time probably influenced trophic status of these reservoirs.

Between the two eutrophic reservoirs, Guarapiranga showed the worst results, especially transparency, total phosphorus, nitrogen and dissolved oxygen concentrations. The mouth of Parelheiros river is a shallow site which receives a high amount of sewage and where there's a strong influence of the surrounding terrestrial area. Other than this, it receives water pumped from Billings reservoir, between 2.0 to $4.0 \mathrm{~m}^{3} . \mathrm{s}^{-1}$, in order to replenish Guarapiranga reservoir according to its fluctuations. The highest values of phosphorus in Guarapiranga reservoir correspond to the first four samples (ranging between 0.07 and $0.32 \mathrm{mg} . \mathrm{L}^{-1}$ ), and the first three were sampled while water was being transferred from Billings reservoir, classified as eutrophic in this study. Aiming to assess the effects of the transfer of water between this two reservoirs, Matsuzaki's study (Matsuzaki 2007 apud Gemelgo et al., 2009) related the higher concentrations of this nutrient in Parelheiros mouth to the pumping of water from Billings reservoir. Shallow systems can be highly susceptible to nutrients movement when not stratified (Leira et al., 2009), and the resuspension of nutrients produces a self-fertilized system (Bicudo et al., 2007). The average concentrations of chlorophyll $a$ registered for Guarapiranga reservoir $\left(29.31 \mu \mathrm{g} . \mathrm{L}^{-1}\right)$ is higher than the average concentrations of chlorophyll $a$ between 2007 and 2011 registered by CETESB (26.22 $\left.\mu \mathrm{g} . \mathrm{L}^{-1}\right)$ CETESB (2013) at the same sampling site, suggesting that algal biomass is increasing.

Fontana et al. (2014) used a short sediment core to study the eutrophication history of this reservoir, built in 1909, and found that it was oligotrophic until 1947, and in 1975 eutrophication began in 
response to the increase in human population. According to the authors, higher $\gamma^{15} \mathrm{~N}$ values in recent sediments indicate greater sewage inputs and low $\mathrm{C} / \mathrm{N}$ values reflect the predominant contribution of algae to sediment organic matter.

Billings reservoir, the other eutrophic reservoir in this study, presented total phosphorus concentrations ranging between 0.04 and $0.07 \mathrm{mg} . \mathrm{L}^{-1}$ during the study period. These results are in agreement with those obtained by CETESB (2013) from 2009 to 2013 (0.03 mg. L $^{-1}$ average concentration) in the same sampling site and other studies conducted in different regions of this reservoir (Moschini-Carlos et al., 2010; Wengrat \& Bicudo, 2011). However, in July 2012 we registered the highest concentration of total phosphorous in this study $\left(1.65 \mathrm{mg} . \mathrm{L}^{-1}\right)$. This period was unusual because of the intensity of rainfall - between June and July 2012 precipitation values were almost twice the historical average, which probably influenced this high concentration of total phosphorus.

Although chlorophyll a concentrations registered for Billings reservoir $\left(40.48 \mu \mathrm{g} . \mathrm{L}^{-1}\right.$ average concentration) are in agreement with those found by Wengrat $\&$ Bicudo (2011) in the central body of the reservoir, they are higher than the average concentrations of chlorophyll $a$ between 2008 and 2011 in the same sampling site $\left(35.65 \mu \mathrm{g} . \mathrm{L}^{-1}\right.$; CETESB 2013), indicating an increase in phytoplankton biomass. High concentrations of chlorophyll $a$ are associated with higher values of $\mathrm{pH}$ and concentrations of dissolved oxygen, because of photosynthesis, as well as high values of turbidity, since phytoplankton biomass can be responsible for reducing transparency in the system.

In the mesotrophic reservoir, Jundiaí, total phosphorus concentrations were similar to those of Billings reservoir. These results were higher than those presented by Sendacz et al. $\left(0.03 \mu \mathrm{g} . \mathrm{L}^{-1} ; 2005\right)$ and average concentrations between 2007 and 2011 (0.03 $\mu \mathrm{g} . \mathrm{L}^{-1}$; CETESB 2013). On the same way, chlorophyll a concentrations (20.25 $\mu \mathrm{g} . \mathrm{L}^{-1}$ average concentration) were higher than the average concentrations between 2007 and 2011 (18.37 $\mu \mathrm{g} . \mathrm{L}^{-1}$ average concentration; CETESB 2013). According to Straškraba \& Tundisi (2013), in cascade reservoirs the negative effects in water quality are transferred along them. Sendacz et al. (2005) found that progressively increasing effects of eutrophication were occurring across three reservoirs of the Upper Tietê System (Ponte Nova, Jundiaí and Taiaçupeba), since the water transferred through channels from the first reservoir (Ponte Nova) involves high inputs of nitrogen and phosphorus to the other reservoirs (Jundiaí and Taiaçupeba). Diffuse contribution and sewage discharge in this reservoir can also affect its water quality. Nevertheless, all concentrations of Total ammonia were below the limit of detection throughout the study period.

On the other hand, in Paiva Castro reservoir, classified as oligotrophic, all total phosphorus concentrations were lower than quantitation limit of the used method, with the highest values of transparency and high concentrations of dissolved oxygen, ranging from $7.6 \mathrm{mg} . \mathrm{L}^{-1}$ to $8.98 \mathrm{mg} . \mathrm{L}^{-1}$. It also had lower concentrations of total nitrogen than the other reservoirs. However, the residence time calculated for this reservoir was of only one day, which can be the explanation for such low concentrations of nutrients.

During this study, non-typical data was observed in rainy and dry periods, with heavier rainfall in June and July 2012, commonly a dry period, which may have been a decisive factor for the lack of observation of seasonality. PCA analysis did not show the formation of groups according to periods, except for four samples from Jundiaí and Paiva Castro reservoirs between June and September 2012, associated with higher transparency and dissolved oxygen concentrations.

This study shows that these important reservoirs of São Paulo state need interventions to avoid the rapid deterioration of water quality, which can jeopardize its uses, especially for human consumption. Conley et al. (2009) suggest that it is prudent, and in most cases essential, to implement a strategy to reduce both phosphorus and nitrogen concentrations in order to control and reverse the enrichment process of systems. Both Guarapiranga and Billings reservoirs have regulations establishing a maximum phosphorus load considering land use in their watersheds (São Paulo, 2006, 2009, respectively). Although reductions in nutrient loading to aquatic ecosystems are utilized all over the world to minimize the symptoms of artificial eutrophication (Cooke et al., 2005), measures such as improving wastewater collection and treatment and controlling nonpoint source inputs are complex activities, especially in urban areas with irregular occupation. However, these measures need to be implemented in order to control and remediate eutrophication in reservoirs. Moreover, such complex systems must be operated considering not only water quantity, but residence time as a factor that can improve water quality, minimizing 
primary production and possibly cyanobacterial blooms. Lee's study (Lee et al., 2012) of a Korean reservoir raised the possibility of inhibiting algae growth establishing strategies for water quality management, such as diminishing the residence time in summer.

\section{Acknowledgements}

This study was part of the project "Characterization of the Waters of the Upper Tietê in relation to the presence of Algae and Cyanobacteria and Toxicity to Aquatic Organisms", with funding from the State Water Resources Fund - FEHIDRO (Comitê de Bacia do Alto Tietê: 2009-AT-475), resulting in the publication of an electronic guide of cyanobacterial identification in these reservoirs (http://laboratorios.cetesb.sp.gov.br/publicacoese-relatorios-2/manuais-e-protocolos). The authors would like to thank CETESB - Environmental Company of São Paulo and the Institute of Botany of São Paulo for their support.

\section{References}

AGÊNCIA NACIONAL DE ÁGUAS - ANA. 2015 [viewed 1 Aug. 2015]. Available from: http://www2. ana.gov.br/Paginas/servicos/outorgaefiscalizacao/ sistemacantareira.aspx

AKOTO, O. and ABANKWA, E. Evaluation of Owabi Reservoir (Ghana) water quality using factor analysis. Lakes and Reservoirs: Research and Management, 2014, 19(3), 174-182. http://dx.doi.org/10.1111/ lre.12066.

AMERICAN PUBLIC HEALTH ASSOCIATION APHA. Standard methods for the examination of water and wastewater. 22nd ed. Washington DC: American Public Health Association, 2005.

BERNHARDT, J., ELLIOTT, J.A. and JONES, I.D. Modelling the effects on phytoplankton communities of changing mixed depth and background extinction coefficient on three contrasting lakes in the English Lake District. Freshwater Biology, 2008, 53(12), 2573-2586. http://dx.doi.org/10.1111/j.13652427.2008.02083.x.

BICUDO, D.C., FONSECA, B.M., BINI, L.M., CROSSETTI, L.O., BICUDO, C.E.M. and ARAÚJO-JESUS, T. Undesirable side effects of water hyacinth control in a shallow tropical reservoir. Freshwater Biology, 2007, 52(6), 1120-1133. http:// dx.doi.org/10.1111/j.1365-2427.2007.01738.x.

BRANDÁO, C.J. org. Guia nacional de coleta e preservação de amostras: água, sedimento, comunidades aquáticas e efluentes líquidos. São Paulo: CETESB; Brasília: ANA, 2011.
BUZELLI, G.M. and CUNHA-SANTINO, M.B. Análise e diagnóstico da qualidade da água e estado trófico do reservatório de Barra Bonita, SP. Revista Ambiente e Água [online], 2013, 8(1), 186-205.

CARDOSO-SILVA, S., NISHIMURA, P.Y., PADIAL, P.R., MARIANI, C.F., MOSCHINI-CARLOS, V., and POMPÊO, M.L.M. Compartimentalizaçấo e qualidade da água: o caso da Represa Billings. Bioikos, 2014, 28(1), 31-43.

CARVALHO, M.C., COELHO-BOTELHO, M.J., LAMPARELLI, M.C., ROQUETTI-HUMAITÁ, M.H., SALVADOR, M.E.P., SOUZA, R.C.R. and TRUZZI, A. Spatial and temporal variations of chlorophyll $a$, plankton and some physico-chemical factors at Billings Complex, São Paulo, Brazil. Verhandlungen der Internationale Vereinigung für Limnologie, 1997, 26, 452-457.

COMPANHIA AMBIENTAL DO ESTADO DE SÃO PAULO - CETESB. Relatório da qualidade das águas interiores do Estado de São Paulo: 2002 [online]. São Paulo, 2003 [viewed 1 July 2014]. Available from: http://aguasinteriores.cetesb.sp.gov.br/publicacoese-relatorios/

COMPANHIA AMBIENTAL DO ESTADO DE SÃO PAULO - CETESB. Relatório da qualidade das águas interiores do Estado de São Paulo: 2011 [online]. São Paulo, 2012 [viewed 1 July 2014]. Available from: http://aguasinteriores.cetesb.sp.gov.br/publicacoese-relatorios

\section{COMPANHIA AMBIENTAL DO ESTADO DE SÃO}

PAULO - CETESB. Relatório da qualidade das águas interiores do Estado de São Paulo: 2012 [online]. São Paulo, 2013 [viewed 1 July 2014]. Available from: http://aguasinteriores.cetesb.sp.gov.br/publicacoese-relatorios

CONlEY, D.J., PAERL, H.W., HOWARTH, R.W., BOESCH, D.F., SEITZINGER, S.P., HAVENS, K.E., LANCELOT, C. and LIKENS, G.E. Controlling Eutrophication: nitrogen and phosphorus. Science, 2009, 323(5917), 10141025. http://dx.doi.org/10.1126/science.1167755. PMid:19229022.

COOKE, G.D., WELCH, E.B., PETERSON, S.A., and NICHOLS, S.A. Restoration and management of lakes and reservoirs. 3rd ed. New York: Taylor \& Francis, 2005. 600 p.

CUNHA, D.G.F., GRULL, D., DAMATO, M., BLUM, J.R.C., LUTTI, J.E.I., EIGER, S. and MANCUSO, P.C.S. Trophic state evolution in a subtropical reservoir over 34 years in response to different management procedures. Water Science and Technology, 2011, 64(12), 2338-2344. http://dx.doi. org/10.2166/wst.2011.826. PMid:22170825.

DAWSON, D., VANLANDEGHEM, M.M., ASQUITH, W.H. and PATIÑO, R. Long-term trends in reservoir water quality and quantity in two 
major river basins of the southern Great Plains. Lake and Reservoir Management, 2015, 31(3), 254-279.

DI BERNARDO, L., MINILLO, A. and DANTAS, A.D.B. Floraçôes de Algas e Cianobactérias: suas influencias na qualidade da água e nas tecnologias de tratamento. São Carlos: LDiBe Editora, 2010.

ESCOBAR, H. Drought triggers alarms in Brazil's biggest metropolis. Science, 2015, 347(6224), 812.

FONTANA, L., ALBUQUERQUE, A.L.S., BRENNER, M., BONOTTO, D.M., SABARIS, T.P.P., PIRES, M.A.F., COTRIM, M.E.B. and BICUDO, D.C. The eutrophication history of a tropical water supply reservoir in Brazil. Journal of Paleolimnology, 2014, 51(1), 29-43. http://dx.doi.org/10.1007/s10933013-9753-3.

GEMELGO, M.C.P., MUCCI, J.L.N. and NAVASPEREIRA, D. Population dynamics: seasonal variation of phytoplankton functional groups in Brazilian reservoirs (Billings and Guarapiranga, São Paulo). Brazilian Journal of Biology, 2009, 69(4), 1001-1013.

GETIRANA, A. Extreme water deficit in Brazil detected from space. Journal of Hydrometeorology, 2015, 17(2), 519-599. http://dx.doi.org/10.1175/ JHM-D-15-0096.1.

HENRY, R., HINO, K., GENTIL, J.G. and TUNDISI, J.G. Primary production and effects of enrichment with nitrate and phosphate on phytoplankton in the Barra Bonita Reservoir (State of Sáo Paulo, Brazil). Hydrobiologia, 1985, 7, 561-573.

ISHII, S. and SADOWSKY, M.J. Escherichia coli in the environment: implications for water quality and human health. Microbes and Environments, 2008, 23(2), 101-108. http://dx.doi.org/10.1264/ jsme2.23.101. PMid:21558695.

KIMMEL, B.L., LIND, O.T. and PAULSON, L.J. Reservoir primary production. In K.W. THORNTON, B.L. KIMMEL, F.E. PAYNE, eds. Reservoir limnology: ecological perspectives. New York: John Wiley \& Sons, 1990.

LEE, S., LEE, S., KIM, S.H., PARK, H., PARK, S. and YUM, K. Examination of critical factors related to summer chlorophyll a concentration in the Sueo Dam reservoir, Republic of Korea. Environmental Engineering Science, 2012, 29(6), 502-510. http://dx.doi.org/10.1089/ees.2011.0070. PMid:22693417.

LEIRA, M., CHEN, G., DALTON, C., IRVINE, K. and TAYLOR, D. Patterns in freshwater diatom taxonomic distinctness along an eutrophication gradient. Freshwater Biology, 2009, 54(1), 1-14. http:// dx.doi.org/10.1111/j.1365-2427.2008.02086.x.

MCCUNE, B. and MEFFORD, M.J. PC-ORD. Multivariate analysis of ecological data. Version 6. Oregon: MjM Software, 2011. 28 p.
MOSCHINI-CARLOS, V.M., FREITAS, L.G. and POMPÊ, M. Limnological evaluation of water in the Rio Grande and Taquacetuba branches of the Billings Complex (São Paulo, Brazil) and management implications. Ambi-Agua, 2010, 5, 47-59. http://dx.doi.org/10.4136/ambi-agua.153.

NOGUEIRA, M.G., HENRY, R. and MARICATTO, F.E. Spacial and temporal heterogeneity in the Jurumirim reservoir, São Paulo, Brazil. Lakes: Research and Management, 1999, 4(3-4), 107-120. http:// dx.doi.org/10.1046/j.1440-1770.1999.00086.x.

OLIVEIRA, F.H.P.C., ARA, A.L.S.C., MOREIRA, C.H.P., LIRA, O.O., PADILHA, M.R.F.P. and SHINOHARA, N.K.S. Seasonal changes of water quality in a tropical shallow and eutrophic reservoir in the metropolitan region of Recife (PernambucoBrazil). Anais da Academia Brasileira de Ciencias, 2014, 86(4), 1863-1872. http://dx.doi.org/10.1590/00013765201420140128. PMid:25590722.

REYNOLDS, C.S. The ecology of Phytoplankton (Ecology, Biodiversity and Conservation). Cambridge: Cambridge University Press, 2006.

SABESP. Complexo Metropolitano. 2015a [viewed 1 Aug. 2015]. Available from: http://site.sabesp.com.br/site/ interna/Default.aspx? secaoId=36

SABESP. Crise hidrica, estratégia e soluçóes da SABESP CHESS (30/04/2015). 2015b, 78 p. [viewed 1 Aug. 2015]. Available from: http://site.sabesp.com.br/ site/uploads/file/crisehidrica/chess_crise_hidrica.pdf

SANT'ANNA, C.L., AZEVEDO, M.T.P., WERNER, V.R., DOGO, C.R., RIOS, F.R. and CARVALHO, LR. Review of toxic species of Cyanobacteria in Brazil. Algological Studies, 2008, 126, 249-263.

SÃO PAULO. Lei no 12.233 , de 16 de Janeiro de 2006. Define a Área de Proteção e Recuperação dos Mananciais da Bacia Hidrográfica do Guarapiranga, e dá outras providências correlatas. Diário Oficial do Estado de São Paulo, São Paulo, 17 jan. 2006, Seção 1, p. 1.

SÃO PAULO. Lei no 13.579 , de 13 de julho de 2009, que define a Área de Proteção e Recuperação dos Mananciais da Bacia Hidrográfica do Reservatório Billings - APRM-B, e dá providências correlatas. Diário Oficial do Estado de São Paulo, São Paulo, 14 jul. 2009, Seção 1, p. 1.

SCHINDLER, D.W. Recent advances in the understanding and management of eutrophication. Limnology and Oceanography, 2006, 51(1, part. 2), 356-363. http://dx.doi.org/10.4319/lo.2006.51.1_ part_2.0356.

SENDACZ, S., MONTEIRO-JUNIOR, A.J., MERCANTE, C.T.J., MENEZES, L.C.B. and MORAES, J.F. Sistemas em cascata: concentraçóes e cargas de nutrientes no Sitema Produtor Alto Tietê, São Paulo. In M.G. NOGUEIRA, R. HENRY and A. JORCIN, eds. Ecologia de reservatórios impactos 
potenciais, açôes de manejo e sistemas em cascata. São Carlos: Rima, 2005, pp. 417-434.

STRASKRABA, M., TUNDISI, J.G. and DUNCAN,

A. State-of-the-art of reservoir limnology and water quality management. In M. STRASKRABA, J.G. TUNDISI and A. DUNCAN, eds. Comparative reservoir limnology and water quality management. Berlim: Kluwer Academic Publishers, 1993.

STRAŠKRABA, M., TUNDISI, J.G. Gerenciamento da qualidade da água de represas. São Paulo: Oficina de Textos, 2013, $300 \mathrm{p}$.

TUNDISI, J.G. and TUNDISI, T.M. Eutrofication of lakes and reservoirs: a comparative analysis, case studies, perspectives. In M. CORDEIRO-MARINO, M.T. AZEVEDO, C.L. SANT'ANNA, N.M. TOMITA and E.M. PLASTINO, eds. Algae and environment: a general approach. São Paulo: Sociedade Brasileira de Ficologia, 1992.

TUNDISI, J.G. Recursos hídricos. Parcerias Estratégicas, 2005, 20, 727-746.
VALENTIN, J.L. Ecologia numérica: uma introdução à análise multivariada de dados ecológicos. Rio de Janeiro: Interciência, 2000, 117 p.

WENGRAT, S. and BICUDO, D.C. Spatial evaluation of water quality in an urban reservoir (Billings Complex, southeastern Brazil). Acta Limnologica Brasiliensia, 2011, 23(2), 200-216. http://dx.doi. org/10.1590/S2179-975X2011000200010.

WHATELY, M. and CUNHA, P. Seminário Guarapiranga: proposição de açóes prioritárias para garantir água de boa qualidade para abastecimento público. São Paulo: Instituto Socioambiental, 2006.

WHATELY, M. and DINIZ, L.T. Água e esgoto na grande Sáo Paulo: situação atual, nova lei de saneamento e programas governamentais propostos. Sáo Paulo: Instituto Socioambiental, 2009.

Received: 19 September 2014 Accepted: 01 February 2016 